\title{
A study on determining of macroinvertebrate biodiversity in water wells with stygobiont species findings
}

Pinar Ozkahya ${ }^{1}$,

\section{Belgin Camur-Elipek ${ }^{2 *}$}

${ }^{1}$ Faculty of Fisheries and Aquatic Sciences, Mugla Sitki Kocman University,

Mugla, Turkey

${ }^{2}$ Department of Biology,

Trakya University, Edirne, Turkey
Although the groundwater ecosystems are diversely populated habitats, it is believed that a lot of species wait for description in these special environments. But, increasing pollution in the world also affects groundwater ecosystems. Macroinvertebrates living as a subterranaean form in groundwaters play an important role in the purification of these habitats and provide usable water quality and they can be extinct before their description. Water wells which are man-made holes to get water from underground are very important environment for a lot of living things. They are made by the digging or drilling of groundwater in underground aquifers and sometimes stygobiont species occurs and can live in these habitats. The wells can create proper environments for living things. In this study, we investigated macroinvertebrate fauna of the wells which are used for drinking/using in a province at Turkish Thrace. For this aim, a total of 80 water wells were sampled during the years 2009-2010. Thus, it was aimed to determine the biodiversity on the macroinvertebrate fauna of these special habitats. As a result, macroinvertebrates belonging to Annelida (Oligochaeta, Hirudinae), Arthropoda (Isopoda, Amphipoda, Diptera), and Mollusca (Gastropoda, Bivalvia) were reported as the first records in the wells of the studied area. Also, an eyeless stygobiont Amphipod species, Niphargus valachicus, was also found at two different water wells.

Key words: water well, macroinvertebrate, subterranean, stygobiont, Turkish Thrace

\section{INTRODUCTION}

It is very difficult to investigate the groundwater environments for macroinvertebrate fauna because of a lot of reasons, such as reach to

\footnotetext{
* Corresponding author. E-mail: belgincamur@yahoo.com; belginelipekcamur@trakya.edu.tr
}

the water body, sampling difficulties, etc. But, it was believed that great populations belonging to subterranean fauna which are diversely populated wait for description in these special habitats (Hancock, Boulton, 2008; Dole-Olivier et al., 2009; Gibert et al., 2009; Stoch, Galassi, 2010; Stein et al., 2012). Therefore, water wells which are man-made holes to get water from 
underground can serve to habit some subterranean fauna. Some specimens which are known as stygobiont can occur and live in these environments.

Although there are a lot of studies which were performed on determining the physicochemical or biological features of water wells, it is seen that a lot of them on biological situation are related with microbiota of the well water (McFeters et al., 1974; Higsmith et al., 1977; Hasde et al., 2002). The data on macroinvertebrates which are living in water wells are very rare (Pesce et al., 1978; Sket, 1990). But, this special habitat may provide very protective areas for macroinvertebrates, especially for stygobiont species. Therefore, it can present very important results on subterranean fauna.

Until now, there is no study on aquatic macroinvertebrates living in water wells of Turkish Thrace. The macroinvertebrate in these special areas has been generally ignored by Turkish researchers up to now. In this study, we examined macroinvertebrate fauna of water wells in the Edirne Province which is located in the European part of Turkey (Turkish Thrace). Especially, it was aimed to find subterranean forms adapted to these special areas to contribute to the subterranean fauna. Thus, it has been aimed to be a preliminary research which will be performed in Turkey on macroinvertebrate fauna in water wells and to obtain geographical distribution by subterranean ways in the world.

\section{MATERIALS AND METHODS}

This study was performed at a total of 80 different water wells (dug well) in the Edirne Province (with 9 different districts) at Turkish Thrace. We sampled a total of 12 wells in the Edirne city center, 11 wells in the Lalapasa district, 4 wells in the Suloglu district, 1 well in the Havsa district, 23 wells in the Uzunkopru district, 9 wells in the Meric district, 5 wells in the Ipsala district, 5 wells in the Kesan district, and 10 wells in the Enez district between the dates from April 2009 to May 2010. The specimens were collected by using an Ek- man grab $(15 \times 15 \mathrm{~cm})$ and simple plankton net (mesh size $400 \mu \mathrm{m}$ ). Remaining material was put into $250 \mathrm{cc}$ plastic bottles including $70 \%$ ethanol for preserving and was sorted and identificated in the laboratory under a binocular stereomicroscope. Also, some physicochemical features of the wells were measured to determine the environmental conditions of the stygobiont organisms living in the sampled waters.

\section{RESULTS AND DISCUSSION}

Although a total of 80 water wells were sampled, the organisms belonging to macroinvertebrates were found at 25 of them only. A total of 158 individuals belonging to Annelida (Oligochaeta, Hirudinae), Arthropoda (Isopoda, Amphipoda, Diptera), Mollusca (Gastropoda, Bivalvia) were determined from the sampling wells. The list and numbers of the macroinvertebrates which have been provided from these localities are presented in the Table. While only one taxon was found in a lot of sampled wells, different taxa belonging to Oligochaeta (one specimen), Isopoda (5 specimens), Amphipoda (3 specimens), and Diptera (12 specimens) were determined at station 43 .

Up to now, the studies which were performed on water wells are especially related with public health. In those studies, the physicochemical properties, microbiological contents, bacteriological situations, and/or heavy metal concentrations of water wells were determined (McFeters et al., 1974; Hasde et al., 2002; Gormly, Spalding, 1979; Lagakos et al., 1986; Chen et al., 1988; Benes et al., 1989; Chen and Wang, 1990; Lawson et al., 1991; Kross et al., 1993; Kurttio et al., 1999; Kaplan et al., 1999; Katkat, 2000; Knobeloch et al., 2000; AlaconHerrera, Martin-Domingues, 2001; Yilmaz, Ekici, 2004; Dursun et al., 2005; Durmaz et al., 2007; Agaoglu et al., 2007; Alemdar et al., 2009; Temamogullar et al., 2010). Especially determining the level of fluoride, nitrite, nitrate, arsenic, and other heavy metal concentration of water wells is a very common issue for the studies on these topics. 
Table. The findings on macroinvertebrates in the sampled wells with a number of organisms

\begin{tabular}{|c|c|}
\hline Taxa & Location number (number of organisms) \\
\hline \multicolumn{2}{|l|}{ Filum: Annelida } \\
\hline \multicolumn{2}{|l|}{ Oligochaeta } \\
\hline Lumbricillus sp. & $\mathbf{1}$ (72 specimens), 61 (1 specimen) \\
\hline Nais elinguis & $\mathbf{4 3}$ (1 specimen) \\
\hline Hirudinae & 46 (2 specimens) \\
\hline \multicolumn{2}{|l|}{ Filum: Arthropoda } \\
\hline \multicolumn{2}{|l|}{ Isopoda } \\
\hline Asellus aquaticus & $\begin{array}{c}\mathbf{1 1} \text { (1 specimen), } 23 \text { (1 specimen), } 27 \text { (1 specimen), } \\
32 \text { (1 specimen), } 43 \text { (6 } \text { specimens), } \mathbf{5 4} \text { (1 specimen), } \\
\mathbf{6 7} \text { (1 specimen) }\end{array}$ \\
\hline \multicolumn{2}{|l|}{ Amphipoda } \\
\hline Niphargus valachicus & 43 (3 specimens), 72 ( 1 specimen $)$ \\
\hline \multicolumn{2}{|l|}{ Diptera } \\
\hline Culiciidae & $\begin{array}{l}\mathbf{1 2} \text { (1 specimen), } 27 \text { (1 specimen), } 29 \text { ( } 2 \text { specimens), } \\
\mathbf{3 1}(2 \text { specimens), } \mathbf{4 3} \text { (4 specimens) }\end{array}$ \\
\hline \multicolumn{2}{|l|}{ Chironomidae } \\
\hline Chironomus anthracinus & 18 (3 specimens), 21 (1 specimen), 36 (1 specimen) \\
\hline Chironomus thummi & $\mathbf{3 6}(2$ specimens $)$ \\
\hline Ceratopoganidae & 43 (8 specimens) \\
\hline \multicolumn{2}{|l|}{ Filum: Mollusca } \\
\hline \multicolumn{2}{|l|}{ Gastropoda } \\
\hline Hydrobiidae & $\mathbf{3}$ (2 specimens), $\mathbf{1 9}$ ( 1 specimen $)$ \\
\hline Planorbiidae & $\begin{array}{l}\mathbf{3} \text { (4 specimens), } \mathbf{4} \text { (1 specimen), } \mathbf{5} \text { (5 specimens), } \mathbf{8} \text { (8 specimens), } \\
\mathbf{1 2} \text { ( } 2 \text { specimens), } \mathbf{1 8} \text { ( } 2 \text { specimens), } \mathbf{1 9} \text { (1 specimen), } 20 \text { (1 specimen), } \\
\mathbf{2 1} \text { (10 specimens), } \mathbf{2 6} \text { (1 specimen), } \mathbf{6 1} \text { (1 specimen), } \mathbf{6 7} \text { (1 specimen) }\end{array}$ \\
\hline Bivalvia & 7 (1 specimen $)$ \\
\hline
\end{tabular}

The studies on macroinvertebrates of these special areas were very rare. But, it was believed that invertebrates in groundwater habitats play an important role in the purification and can provide usable water quality (Humphreys, 2006; Murray et al., 2006). In a study concerned with aquatic macroinvertebrates in water wells, unpigmented specimens belonging to Isopoda were recorded (Sket, 1990). In this mentioned study which has been performed at Cyprus, it was also reported that Amphipoda (Bogidiella cypria) and some species belong to Turbellaria, Copepoda, Gastropoda, and Oligochaeta (Sket, 1990). In another study on underground water sources including some water wells in Greece by Pesce et al. (1978), the specimens belonging to Copepoda, Amphipoda, Syncaridea, and Isop- oda were reported. In this mentioned study, it was recorded that an Amphipod species, Niphargus orcinus, was recorded in a freshwater well (Pesce, 1978).

In our study, a total of four eyeless Amphipod specimens belonging to the species Niphargus valachicus were found at two water wells which have 7 and $11 \mathrm{~m}$ depth. The amphipods belonging to the Niphargidae family are known including the specimens that have adapted to subterranean conditions. This stygobiontic invertebrate is known as perfectly adapted to groundwater habitats, has translucent, blind, exhibit enhanced tactile sense organs and lacks circadian periodicity (Stein et al., 2012). Until now, a total of 9 species belonging to the genus Niphargus from Turkey has been reported (Akbulut et 
al., 2001; Fiser et al., 2009; Karaman, 2012). In the past, only one species from this stygobiont family, $N$. valachicus, was reported from Turkish Thrace at three different localities which are located at Kirklareli and Istanbul (Fiser et al., 2009). Therefore, these findings on $N$. valachicus in our study are the first reports for the studied area (Edirne province and the sampled wells). In the sampling localities where $N$. valachicus was observed, salinity was measured as 0.13 and $0.09 \%$, dissolved oxygen was measured as 1.8 and $3.8 \mathrm{mg} / \mathrm{L}$, total hardness was found at soft and medium hard quality at the wells. In station 43, other benthic organisms with N. valachicus, the species Nais elinguis from Oligochaeta, Asellus aquaticus from Isopoda, Culicidae and Ceratopogonidae from Diptera were also observed. But, there was no benthic macroinvertebrate in station 72 except the stygobiont Amphipod N. valachicus.

Also, the species Nais elinguis which is known as a very cosmopolite form in aquatic ecosystems (from freshwater sources to brackish water bodies) was determined at only one station in this study (Table). The species Lumbricillus which is another species from Oligochaeta was found at two water wells. Although it is known that Isopoda includes the species adapted to special underground conditions, there is no finding on subterranean isopods in this study. But, we have recorded a very common species in freshwater ecosystems, Asellus aquaticus, from 7 different localities in this study. The adults of species belonging to order Diptera can fly and they can find different suitable habitats for egging. Therefore, it is not surprise to find the larval-pupal stage of them in water wells. We have found the specimens belonging to the families Ceratopogonidae and Chironomidae in this study. Especially, two common species, Chironomus anthracinus and Chironomus thummi, belonging to Chironomidae were found at the studied water wells. Although, a total of 41 valves belonging to Gastropoda from 12 different localities were found, only one valve belongs to Bivalvia from one locality. None of them has organisms.

\section{CONCLUSIONS}

Consequently, in this study, macroinvertebrate fauna with some of them adapted to subterranean conditions has been reported from water wells in the Edirne Province. All findings in this study are the first record for the studied wells. To obtain subterranean forms, water wells can be providing suitable habitats to researchers. Therefore, it was suggested that similar studies should be increased in water wells.

\section{ACKNOWLEDGEMENTS}

Some findings in this study were provided from the author Ozkahya's MsC thesis which has been supported by the research fund of Trakya University with project TUBAP-2009/23.

Received 6 June 2015 Accepted 20 August 2015

\section{References}

1. Akbulut M, Sezgin M, Culha M, Bat L. On the occurrence of Niphargus valachicus Dobreanu \& Manolache 1933 (Amphipoda: Gammaridae) in the Western Black Sea Region of Turkey. Turk J Zool. 2001; 25: 235-9.

2. Alacon-Herrera MT, Martin-Domingues IRM. Well water fluoride, dental fluoreosis and bone fractures in the Guadiana valley of Mexico. Fluoride. 2001; 2(34): 139-49.

3. Agaoglu S, Alisarli M, Alemdar S, Dede S. Van bolgesi icme ve kullanma sularinda nitrat ve nitrit duzeylerinin arastirilmasi. YYÜ Vet Fak Derg. 2007; 18(2): 17-24.

4. Alemdar S, Kahraman T, Agaoglu S, Alisarli M. Bitlis ili icme sularinin bazi mikrobiyolojik ve fizikokimyasal ozellikleri. Ekoloji. 2009; 19(73): 29-38.

5. Benes V, Pekny V, Skorepa J, Vraba J. Impact of diffuse nitrate pollution sources on groundwater quality some examples from Czechoslovakia. Environ Health Perspect. 1989; 83: 5-24. 
6. Chen C, Wu M, Lee S, Wang J, Cheng S, Wu H. Atherogenicity and carcinogenicity of high-arsenic artesian well water: multiple risk factors and related malignant neoplasms of blackfoot disease. Arterioscler Thromb Vasc Biol. 1988; 8: 452-60.

7. Chen C, Wang C. Ecological correlation between arsenic level in well water and age-adjusted mortality from malignant neoplasms. Cancer Res. 1990; 50: 5470-4.

8. Dole-Olivier MJ, Castellarini F, Coineau C, Galassi DMP, Martin P, Mori N, Valdecasas A., Gibert J. Towards an optimal sampling strategy to assess groundwater biodiversity: comparison accross six European regions. Freshwater Biol. 2009; 54: 777-96.

9. Durmaz H, Ardic M., Aygun O. Sanliurfa ve yoresindeki kuyu sularinda nitrat ve nitrit duzeyleri. YYÜ Vet Fak Derg. 2007; 18(1): 51-4.

10. Dursun S, Karatas M., Ozturk E. Konya il merkezindeki kuyu icme sularinin florur seviyelerinin tespit edilmesi. SU Fen Fak Derg. 2005. 26: 63-70.

11. Fiser C, Camur-Elipek B, Ozbek M. The subterranean genus Niphargus (Crustacea. Amphipoda) in the Middle East: A faunistic overview with descriptions of two new species. Zool Anz. 2009. 248: 137-50.

12. Gibert J, Cluver D, Dole-Olivier MJ, Malard F, Christman MC, Deharveng L. Assessing and conserving groundwater biodiversity: synthesis and perspectives. Freshwater Biol. 2009; 54: 930-41.

13. Gormly JR, Spalding RF. Sources and concentrations of nitrate-nitrogen in ground water of the central Platte region. Groundwater. 1979; 17(3): 291-301.

14. Hancock PJ, Boulton AJ. Stygofauna biodiversity and endemism in four alluvial aquifers in eastern Australia. Invertebr Syst. 2008; 22: $117-26$

15. Hasde M, Ogur R, Tekbas OF. Ankara il merkezinde bulunan askeri birliklerdeki kuyu sularinin polimeraz zincir reaksiyon sistemi ile mikrobiyolojik analizlerinin yapilmasi. Gulhane Tip Dergisi. 2002; 44(4):
$373-7$.

16. Higsmith AK, Feeley JC, Skaliy P, Wells JG, Wood BT. Isolation of Yersinia enterocolitica from well water and growth in distilled water. Appl Environ Microbiol. 1977; 34(6): 745-50.

17. Humphreys WF. Aquifers: the ultimate groundwater-dependent ecosystems. Austral J Bot. 2006; 54: 115-32.

18. Kross BC, Hallbe GR, Bruner R, Cherryholmes $\mathrm{R}$, Johnson $\mathrm{K}$. The nitrate contamination of private well water in Iowa. Am J Public Health. 1993; 83(2): 270-2.

19. Katkat G. Tekirdag il sinirlari dahilinde bazi icme suyu kuyularinin fiziksel ve kimyasal analizleri [MsC Thesis]. Edirne, Turkey: Trakya University; 2000.

20. Kaplan M, Sonmez S, Tokmak S. AntalyaKumluca yoresi kuyu sularinin nitrat icerikleri. Turk J Agric For. 1999; 23: 309-13.

21. Karaman GS. New data of the subterranean family Niphargidae (Amphipoda, Gammaridea) from Turkey (Contribution to the knowledge of the Amphipoda 259). Nat Montenegr. 2012; 11(1): 53-71.

22. Knobeloch L, Sanla B, Hogan A, Postle J, Anderson $\mathrm{H}$. Blue babies and nitrate-contaminated well water. Environ Health Perspect. 2000; 108(7): 675-8.

23. Kurttio P, Pukkala E, Kahelin H, Auvinen A, Pekkanen J. Arsenic concentrations in well water and risk of bladder and kidney cancer in Finland. Environ Health Perspect. 1999; 107: 705-10.

24. Lagakos SW, Wessen BJ, Zelen M. An analysis of contaminated well water and health effects in Woburn, Massachusetts. J Amer Statist Assoc. 1986; 81(395): 583-96.

25. Lawson HW, Braun MM, Glass RI, Stine SE, Monroe SS, Atrash HK, Lee LE, Englende SJ. Waterborne outbreak of Norwalk virus gastroenteritis at a southwest US resort: role of geological formations in contamination of well water. Lancet. 1991; 337: 1200-4.

26. McFeters GA, Bissonnette GK, Jezeski J, Thomson CA. Comparative survival of indicator 
bacteria and enteric pathogens in well water. Appl Microbiol. 1974; 27(5): 823-9.

27. Murray BR, Hose GC, Eamus D, Licari D. Valuation of groundwater dependent ecosystems: a functional methodology incorporating ecosystem services. Austral J Bot. 2006; 54: 221-9.

28. Pesce GL, Maggi D, Ciocca A, Argano R. Biological researches on the subterranean phretic waters of northern Greece. Proceedings of Symposium international sur la zoogeographie et lecologie de la grece et des regions avoisinantes; Athenes, Avril; 1978.

29. Sket B. Isopoda (Crustacea; isopoda; microcharon. jaera. proasellus) and other fauna in hypogean waters of southern Cyprus. J Speleol. 1990; 19: 39-50.

30. Stein H, Griebler C, Berkhoff S, Matzke D, Fuchs A, Hahn HJ. Stygoregions - a promising approach to a bioregional classification of groundwater systems. Sci Rep. 2012; 2(673): 1-9.

31. Stoch F, Galassi MP. Stygobiotic crustacean species richness: a question of numbers, a matter of scale. Hydrobiologia. 2010; 653: 217-34.

32. Temamogullar F, Dincoglu AH. Sanliurfa ve cevresindeki kuyu sularinda cinko ve selenyum duzeyleri. Kafkas Univ Vet Fak Derg. 2010; 16(2): 199-203.
33. Yilmaz O, Ekici K. Van yoresinde icme sularinda arsenik kirlenme duzeyleri. YYÜ Vet Fak Derg. 2004; 15(1-2): 47-51.

\section{Pinar Ozkahya, Belgin Camur-Elipek}

\section{VANDENS ŠULINIŲ MAKROBESTUBURIŲ IVAIROVE்}

\section{Santrauka}

Žmogaus iškasti šuliniai požeminio vandens naudojimui yra svarbi aplinka požemio gyvūnams. Kadangi jie iškasti ar išgręžti iki vandeningojo horizonto, kartais juose galima aptikti stygobiontų. Šiame tyrime buvo ištirti Trakijos provincijos (Turkija) geriamojo vandens šulinių makrobestuburiai. Siekiant ịvertinti makrobestuburių bioịvairovę šioje specifinèje aplinkoje, 2009-2010 m. buvo ištirta 80 šulinių pavyzdžių. Pirmą kartą šios teritorijos šulinių aplinkoje buvo nustatyti makrobestuburiai, priklausantys žieduotosioms kirmèlèms (Oligochaeta, Hirudinae), nariuotakojams (Isopoda, Amphipoda, Diptera) ir moliuskams (Gastropoda, Bivalvia). Beakè stygobiontų šoniplaukų rūšis Niphargus valachicus buvo aptikta dviejuose skirtinguose šuliniuose.

Raktažodžiai: vandens šuliniai, makrobestuburiai, požemių gyvūnai, Turkija, Trakija 